\title{
Education System Construction of Building Environment and Energy Engineering Facing the Actual Engineering
}

\author{
W.H. TANG*, X.D. CHENG, X.Q. WANG, W.B. ZHENG \& C. ZHANG \\ School of environmental engineering, Wuhan Textile University, Wuhan, China
}

\begin{abstract}
For purpose of cultivating talents who are good at solving practical engineering problems, has innovative consciousness and preliminary scientific research ability, under the guidance of the concept of modern higher engineering education, and through a series of teaching research projects being put into practice, the applied talents cultivating education system of Building Environment and Energy Engineering (BEEE) of Wuhan Textile University has gradually formed, this paper summarizes professional experiences and achievements of our many years teaching; The key is introduced that practice teaching links which includes experiment, practice, curriculum design, graduation design and innovation education, mainly raise student's engineering practice ability.
\end{abstract}

KEYWORD: Wuhan Textile University; Building Environment and Energy Engineering; Application talents; Cultivating; Engineering education; Construction

\section{INTRODUCTION}

BEEE is more and more closely with the building, thermal energy engineering, energy power, machinery, automatic control industry, with the rapid development of science and technology and professional new technology constantly emerging, building indoor environment control is changing from the simple adjustment into intelligent adjustment, green and energy saving, professional teaching system should adapt itself to the development of science and technology. BEEE, as a typical technology applied professional, how to build a teaching system, which has solid professional foundation, wide professional direction and can cultivate outstanding applied talents[1], is a problem to be urgently solved in the face of professional teaching staffs.

\section{FACING THE ACTUAL ENGINEERING APPLICATION TALENTS TEACHING SYSTEM}

To cultivate high quality engineering application talents who has solid professional foundation and strong practice ability[1], must widen the basis knowledge in comprehensive basic quality theory teaching and professional quality theory teaching, strengthen the skill training in professional practice teaching; According to the new engineering teaching system of our BEEE, talent training is divided into three stages which are comprehensive basic quality training link, professional basis quality training link, and engineering practice ability and innovation ability training link, the cultivation time of the three stages is respectively 2 years, 1 year, 1 year, referred to as the "2+1+1" scheme(To Grant Engineering Bachelor) [6], the framework of BEEE teaching system is shown in figure 1.[2-7]

Two years comprehensive basic quality training link is as follow: in the first and the second academic year, students mainly accept comprehensive basic quality education which contain the humanities, social sciences, important natural sciences, the professional ethics, personality behavior, psychology health, etc courses learning and cultivation of independent thinking and learning ability.

One year professional basis quality training link is as follow: in the third academic year of undergraduate, emphasis on the importance of the solid professional basis education on students' project practice ability and innovation ability, we want them mainly to learn the professional technical foundation courses which contain fluid mechanics, engineering thermodynamics, heat transfer, pipe net for fluid supply, heat and mass transfer principle and equipment, building environment etc. 


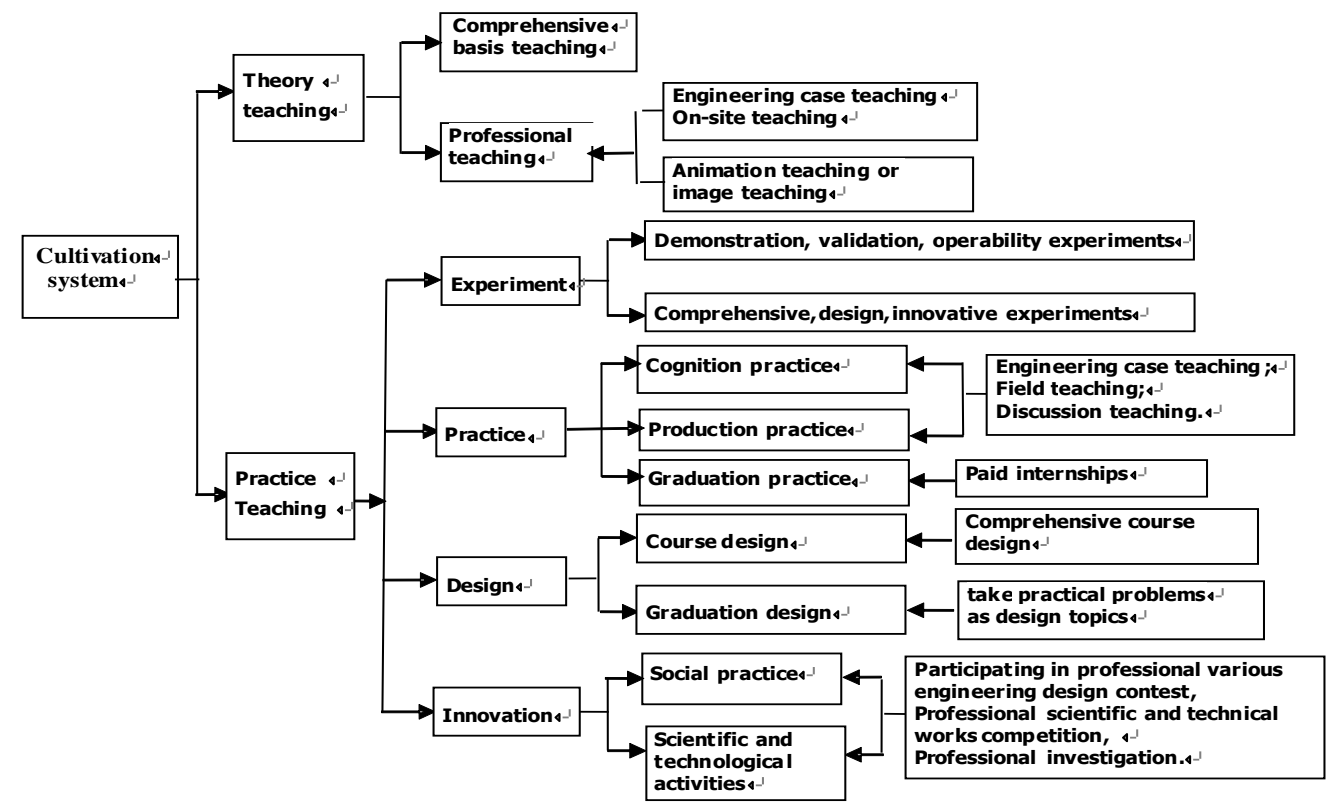

Figure 1 Engineering applied talents training mode

One year engineering practice ability and innovation ability training link means that: in the last academic year of undergraduate, according to the student's personal interest and employment market situation, they are separated to learn BEEE major compulsory courses and professional elective courses, such as heating ventilation air conditioning (HVAC), cold/heat source engineering, construction equipment automation, building water supply and drainage, gas engineering, installation technology of building equipment, etc. Focusing on training the students' project practice ability and innovation ability, we take many ways such as comprehensive experiments, engineering practice, course design, graduation design, small tasks, students' participating in various professional engineering design competitions and professional science and technology activities.

\section{BEEE APPLICATION TALENTS TRAINING LINKS}

\subsection{The professional quality training link}

In today's society, students' employment is a dynamic process, the market need such talents which shouldn't have fixed professional direction, consciousness stationary, rigid thinking and single skills, but should have extensive professional knowledge and can adapt to the changeful competition. Therefore, the professional quality training link needs to have solid professional basis education and many professional directions, our effective way is to strengthen learning of professional common engineering technology principle and method which is contained in three platform courses we built ( pipe net for fluid supply, heat and mass transfer principle and equipment, and building environment)[7]. The three platform courses mainly expound fluid transmission and distribution, heat and mass transfer, air quality guarantee, etc.

Our professional quality teaching system of BEEE consists of the professional basis courses(fluid mechanics, engineering thermodynamics, heat transfer), the professional platform courses (pipe net for fluid supply, heat and mass transfer principle and equipment, building environment), the professional direction courses (HVAC, cold/heat source engineering, construction equipment automation, building water supply and drainage, gas engineering, installation technology of building equipment) and the practice courses(engineering practice, course design, graduation design). we put forward a undergraduate engineering teaching methods which is that "the general professional technical principles are imparted by three professional platform courses, professional various technical applications are imparted by professional direction courses, and the professional engineering design essentials, technical measures, the construction requirements and other technical specifications are imparted by practice courses."[7]

The traditional teaching of specialized core courses and specialized courses focus on the imparted knowledge and theory analysis, this is beneficial to develop students' thinking ability, but is not effective to train students' engineering practice ability. In view of this problem, besides the traditional teaching method, we strengthen the case teaching, discussion teaching, on-site teaching and image teaching etc, the students' homeworks are comprehensive exercises and small-scale design instead of original simple exercises and thinking questions; The above method not only enables students to easily accept and master the learned 
knowledge, but also is useful of training students' project practice ability.

\subsection{Engineering practice ability and innovation ability training links}

\subsubsection{Experiment}

Besides the professional course experiments setting alone, we developed a comprehensive experimental platform suitable for BEEE[2], which consists of cold and heat sources, water pipeline net, wind pipeline net, air treatment equipment, air conditioning detection system and automatic control system. On the platform, the following experiments can be done: 1)pipe-net characteristic curve test; (2)air conditioning system operation PID conditioning control experiment; (3)filter performance test; (4)fan noise attenuation experiment of broadband muffler; (5)supply air airflow organization test; (6) performance test of air diffuser; (7)thermal performance testing of surface cooler on dry and wet conditions; 8)indoor air heat, moisture environmental assessment experiment; (9)chiller water pipe network system hydraulic analysis experiments; (10) air duct system hydraulic balance adjustment experiments, etc. Because of the designed experiments covering most of professional courses and being comprehensive, it can cultivate students' preliminary scientific research ability.

\subsubsection{Practice}

Our BEEE engineering practice includes cognition practice[5], production practice[4] and graduation practice [3]. Cognition practices' aim is to let students know the actual specialty situation and understand that this specialty is engaged in the nature of works and tasks. The cognition practice units we selected are as follow: such as large hotels, office buildings and shopping centers which must be equipped with air conditioning system, HVAC equipment manufacturing enterprises and design enterprises; These units can leave a good impression to students, and have a good effect for students loving the professional. Production practice refers to thoroughly participating in actual work environment. The talents trained by BEEE should solve specific technical problems of HAVC design, construction, supervision and system operation management etc. The choice of production practice units are given priority to HAVC design units, HAVC system installation units and professional equipment manufacturers. For example, some HAVC engineering installation units need many new employees each year (this is our focus on), our students can go to work or on shift, they learn to observe the construction details, and learn experiences of solving practical problems and other production knowledge which can not be known in the class. Sometimes, we use the limited practice funds to purchase some old professional equipments and parts or we receive free donated equipments by some manufacturers, and let students dismount and install these equipments, it is helpful for students fully understanding performance and structure of equipments; Besides, we use our school resources, carrying on practice, such as visiting boiler room, water pump room, student mess hall VRF/VRV air conditioning system, library central air conditioning system etc. Graduation practice refers to deep understanding certain HAVC engineering design and construction gist and technical specification, it is well prepared for graduation design, this part is specifically introduced in 3.2.4.

\subsubsection{Course design}

Our BEEE course designs keep up with the latest achievements of science and technology and the latest industry standards[5], they are as follow: refrigeration station course design (1 week),boiler room course design ( 2 weeks), heating course design (2 weeks), ventilation course design (1 week),air conditioning course design (2 weeks), gas supply course design (1 week), refrigeration and air conditioning and ventilation system comprehensive course design (4 weeks), air conditioning and smoke control system comprehensive course design (3 weeks), and gas boiler room and residential heating system comprehensive course design (5 weeks); During above course designs, students are considered qualified until they finish at least total 11 weeks design; On the other hand, we have set up a set of scientific evaluation system which is used to examine the students' practical ability. In the details of course design, the requirements are that drawings quality reaches to construction drawing design depth.

\subsubsection{Graduation design}

Based on school-enterprise cooperation of 'learning combined with production', our school has nearly 10 years good cooperation relationship with Suzhou Shenghui Engineering Co. LTD (Taiwan-owned enterprise)[3], which specializes in civil air conditioning, clean air conditioning design and installation; Every year the company receive many air conditioning project orders, and invite our students to go to work or 'On Shift' ( paid wage) at their project on-site, our students may participate in construction management, assistant design and technology study, we ask students to get ready for half a year's practice from the second half of the seventh semester, and let students take the practical problems as their graduation design topics. Through paid internships, students closely contact various forms of HAVC engineering, participate in HAVC project construction, learn construction standards, 
deeply understand professional content, write graduation practice reports with plentiful content and their viewpoints, the graduation design drawings can come up to technical requirements which the construction drawings meet, many students' graduation designs get excellent grades.

\subsubsection{Innovation quality training}

we established the professional comprehensive experimental platform, the engineering training base, and Guangzhou Honda automobile assembly shop air conditioning and ventilation system simulation center [6], all of them have reached basic characteristics of the actual project, these can provide students with the innovation training environment. Here, students can also independently select topics by themselves, set about their innovation experiment, declare their research project, and participate in all kinds of professional engineering design competitions and various innovation competitions.

\section{IMPLEMENTATION EFFECT}

Every year our teaching training plans are revised, especially in the practice teaching, the following is class hour contrast of practice teaching links after seven years, as is shown in table 1.

Table 1. Class hour contrast of practice teaching link

\begin{tabular}{|c|c|c|}
\hline \multirow{2}{*}{ Practice teaching link } & \multicolumn{2}{|c|}{ Class hour } \\
\cline { 2 - 3 } & 2004 grade & 2011 grade \\
\hline Experimental teaching & 30 class hours & 40 class hours \\
\hline All kinds of practices & 8 weeks & 10 weeks \\
\hline Course design & 9 weeks & 11 weeks \\
\hline $\begin{array}{c}\text { Graduation design } \\
\text { Innovation quality } \\
\text { training }\end{array}$ & 12 weeks & 14 weeks \\
\hline \multicolumn{2}{|c}{ class hours } & 160 class hours \\
\hline
\end{tabular}

Data in the table shows that class hour of all practice teaching are increased after reform, especially the experiment and innovation respectively increasing $33 \%$ and $400 \%$, the applied talents training is fully implemented.

since application of above teaching achievements, more than 700 students of BEEE are benefited, the most significant is that the engineering applied college students are very popular, college graduates disposable employment rate reaches to $95 \%$, which lies in the top three in Wuhan Textile University. Seen from the teaching effect, excellent graduation designs selected by peer experts in Hubei province were up to 40 in the past six years; Every year percentage of college graduates, who was admitted to master graduate student for the key university, was close to $18 \%$;Each year one student took part in
'Artificial Environment Engineering Discipline Scholarship Competition' held by The National Professional Guidance Committee, and won the second prize or the third prize; In nearly five years nine students were winners in "'Emerson Cup' the National Digital Scroll Central Air Conditioning Design Application Competition", some students had 'Future Star' award (only three people throughout the country to win the award); Six papers wrote by students were published in the national professional conference proceedings or professional periodical journals; Five students obtained third prize in "Hubei Province 'Challenge Cup' College Students' Extracurricular Science and Technology Works Competition"; The students' outstanding innovation ability is raising our school reputation and influence, our BEEE was named as 'Hubei Province Brand Professional' in 2006, and one of the six advantage majors of Wuhan Textile University.

\section{ACKNOWLEDGMENT}

The study was supported by Teaching Research Project of Hubei Provincial Department of Education (Grant No.2002165), Teaching Research Project of Wuhan Textile University (200410), Teaching Research Project of Wuhan Textile University (2006035), Teaching Research Project of Wuhan Textile University (200701), Teaching Research Project of Hubei Provincial Department of Education (Grant No.2010251).

\section{REFERENCES}

[1] J.B.Yuan and J.L.Zheng. Engineering practice ability: the key of training applied talents. Higher Engineering Education Study2002; 3: 35-37[in Chinese].

[2] C.L.Yuan and X.D.Cheng. Development of Building Environment and Energy Engineering professional comprehensive experimental platform. Research and Exploration in Laboratory2008; 27(1):38-41[in Chinese].

[3] W.H.Tang. Adaptation to the situation, the reform of graduation practice and graduation design. Wuhan: Wuhan Press. 2006[in Chinese].

[4] Y.Z. Wu. Building Environment and Energy Engineering production practice reform and innovation. Wuhan: Wuhan Press. 2006[in Chinese].

[5] W.B. Zheng. Building Environment and Energy Engineering professional practicality course study. Textile Education 2006; 4:41-43[in Chinese].

[6] C.Zhang and W.H.Tang, etc. Exploration and practice of facing modern engineering Building Environment and Energy Engineering innovative talent training mode. The Sixth Refrigeration and Air Conditioning Discipline Development and Teaching Research 2010; 7:75-78[in Chinese].

[7] W.H.Tang and W.B.Zheng. Construction of professional courses platform of Building Environment and Energy Engineering. Journal of Wuhan Institute of Science and Technology 2006; (02):105-108[in Chinese]. 